\title{
Den antikke olympiade
}

af Nanna Westergård-Nielsen

Helligdommen og sportscentret Olympia på Peloponnes i Grækenland er det ældste og bedst kendte hjemsted for de antikke sportslege og vel også det sted, hvortil flest materielle og litterære kilder kan henføres.

De $\varnothing$ vrige antikke sportslege, de panhellenske (Athen), de pythiske (Delfi) og de istmiske lege (Korinth) adskiller sig væsentlig fra de Olympiske Lege, idet de også omfattede konkurrencer i musiske discipliner. De olympiske lege var udelukkende sportslege.

\section{De olympiske leges oprindelse}

Begrebet sportslege har sandsynligvis oprindelse i de antikke gravlege, som vi kender dem beskrevet i Homers Iliade (Il. 23). Achilleus fejrer sin trofaste ven Patroklos' bålfærd med løb og væddel øbsk ørsel. Sportslege i forbindelse med gravfæstelse kendes også fra etruskerne, både i form af gravmalerier og litterære kilder.

Iliaden antages at være nedskrevet i 700 tallet f. Kr. Et tidspunkt der passer meget godt med det traditionelt anerkendte årstal $776 \mathrm{f}$. Kr. for den første

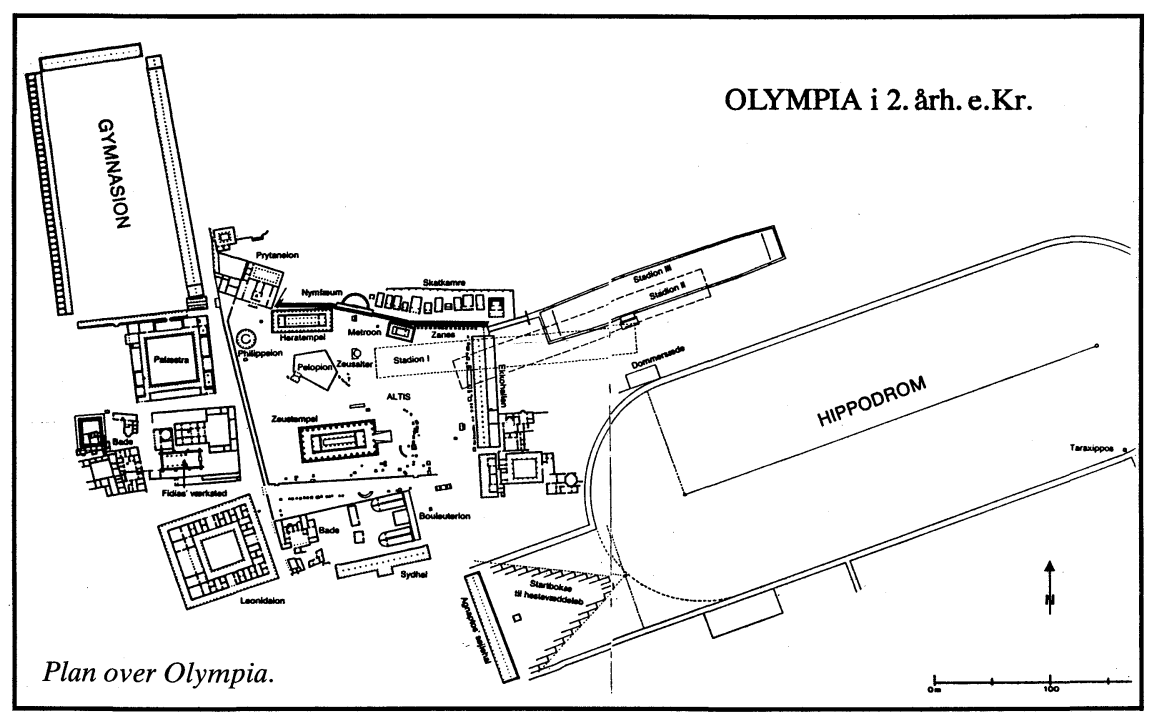


olympiade afholdt i Olympia. Kilden er de antikke sejrslister fra Olympia, der er bevaret i uddrag hos forskellige antikke forfattere.

Olympia var først og fremmest en helligdom for Zeus. Og de olympiske leges oprindelse sættes i forbindelse med religiøse handlinger og gravlege. Selvom det officielt anerkendte indstiftelsestidspunkt var $776 \mathrm{f}$. Kr., fors $\emptyset \mathrm{gte}$ grækerne at føre sportslegenes oprindelse meget længere tilbage - tilbage til en mytologisk verden, som den græske digter Pindar beskriver i 400 tallet $\mathrm{f}$. $\mathrm{Kr}$. I Pindars olympiske oder føres sportslegenes begyndelse tilbage til de gravlege, der blev afholdt til ære for heroen Pelops. Ved at lade en anden heros, Herakles, deltage i en løbekonkurrence efter at have ofret ved Pelops' grav, knytter Pindar sportslegene yderligere sammen med mytologi og religion. Han understreger endvidere Herakles betydning for Olympia og de Olympiske Lege ved at fortælle, at det var Herakles, som havde opmålt det hellige område i Olympia, Temenos, og som havde bragt det vilde oliventræ til Olympia - det oliventræ, med hvis blade de sejrende atleter blev bekranset.

Pausanias, som skrev en Grækenlandsbeskrivelse 6-700 år senere, er en af vore mest udførlige kilder, og han lader også Herakles have del i sportslegenes indstiftelse, men forsøger desuden at overbyde tidligere forfattere med hensyn til Zeushelligdommens alder, idet han tilskriver den Zeus' far Kronos. Efter, at Zeus havde sat sin far fra magten, overgik helligdommen til Zeus.

\section{Olympia - helligdom og sportscentrum}

Olympia ligger i landskabet Elis på det nordvestlige Peloponnes. De to floder Kladeos og Alpheios, der mødes ved foden af Kronos-højen, har i årtusinders forløb dannet en frugtbar flodslette mellem omgivende bjerge. På det svagt skrånende terræn mellem flodsletten og Kronos-højen, ligger Olympia. I dag ses en lys og åben pinjelund. Mellem de spredte træstammer ses rester af antikke bygningers murværk og søjler.

Også i oldtiden var stedet dækket af en lund, altis. Selve helligdommen bestod af et helligt område temenos omkranset af en mur. Inden for muren lå de to store templer for Zeus og Hera, og imellem dem lå altre for andre guder. Nogenlunde i midten af temenos fandtes de ældste offerpladser - Pelops' grav og det store Zeus-alter. En langstrakt terrasse afsluttede området mod nord og heroppe lå 12 skatkamre bygget af rige græske kolonier i blandt andet Syditalien og på Sicilien. Mod $\varnothing$ st dannede to lange søjlehaller - stoaer - grænsen til stadion og hestevæddeløbsbanen, der lå uden for det hellige område. Ligeledes uden for det hellige område mod vest og syd lå andre sportsanlæg, gymnasion, palæstra samt de administrative bygninger prytaneion og bouleuterion.

De synlige bygningsrester i Olympia er hovedsagelig fra tiden mellem $600 \mathrm{f}$. $\mathrm{Kr}$ og ca. $200 \mathrm{f}$. Kr. Men andre mere sparsomme fund vidner om bebyggelse allerede i 2 . årtusind f. Kr. Rige arkæologiske fund af offergaver af terracotta 


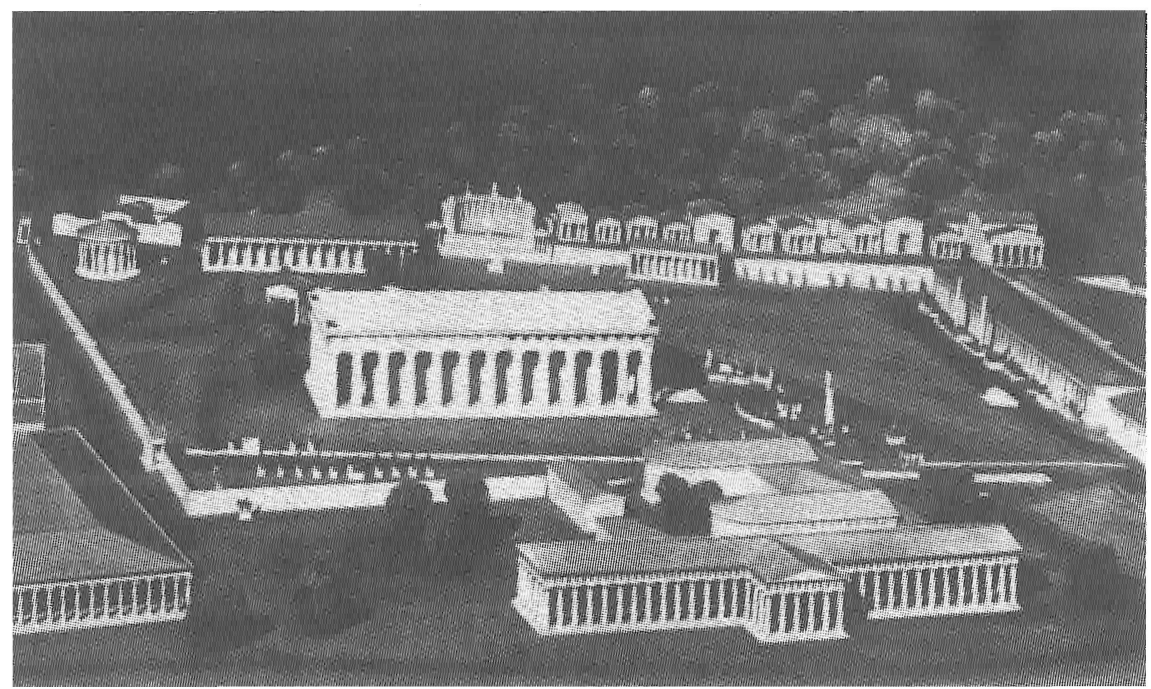

Rekonstrueret model af Olympia, Museet i Olympia.

og bronze viser, at Olympia blev en betydelig helligdom i løbet af 9., 8. og 7. århundrede før Kristus, dvs. i geometrisk og arkaisk periode. Fundtyper, som våben og statuetter af krigere, viser, at det på denne tid var den mandlige krigsgud Zeus, der blev dyrket i Olympia. Selvom sejrslisterne starter i det 8. årh., har der måske eksisteret enkelte sportslege $\mathrm{i}$ forbindelse med helligdommen allerede i det 9 . årh. f. Kr.

I det følgende skal vi gennemgå det olympiske sportsprogram, som det typisk må have udformet sig i 400 tallet f. $\mathrm{Kr}$.

\section{De olympiske lege - dag for dag}

De Olympiske Lege var en fælles græsk panhellensk fest, det vil sige en fest, hvor alle frie ustraffede grækere af hankøn kunne deltage. Fremmede og slaver kunne deltage som tilskuere, men kvinder var udelukkede såvel fra at deltage som fra at se på. Hvis en kvinde blot krydsede Alpheios - floden, mens legene stod på, blev hun straffet med døden.

Kun én gang vides dette forbud at være blevet overtrådt, og det var da en enke fra Rhodos tog til Olympia forklædt som mand, fordi hun så brændende $\emptyset n s k e d e$ at se sin søn bokse. Da han sejrede, sprang hun i begejstring over barrieren til kamppladsen og glemte at holde sammen på sin kappe, der blæste op og afslørede hende.

Hvert fjerde år drog herolder ud fra Olympia til alle bystater i Grækenland for at meddele, at nu var det tid for atleterne at forberede rejsen til Olympia, samt for at proklamere våbenhvilens start. Det var hellig lov, at der i Grækenland skulle herske landefred i de tre måneder, forberedelserne og afviklingen af de olympiske lege stod på. 
Selve legene blev afholdt sidst på sommeren i den såkaldte olympiske måned, mellem den 6. august og den 29. september, afhængig af, hvornår det var fuldmåne. Fuldmånedagen var olympiadens midterste dag.

Afviklingen af legene fulgte et bestemt program, hvor religiøse handlinger vekslede med sportslige konkurrencer. Ved hjælp af Pindar og Pausanias er det muligt af rekonstruere den olympiske kalender.

En måned før legenes start ankom atleterne til byen Elis, som stod for legene i Olympia. De trænede i Elis' gymnasier under lige vilkår og under opsyn af ti dommere. Når træningsmåneden var gået, drog atleterne til Olympia, hvor de boede i gymnasion.

Oprindeligt var legene koncentreret på en enkelt dag, fuldmånedagen i den olympiske måned. Der blev ofret til Pelops og til Zeus, og derefter afholdtes en konkurrence i l $\varnothing b$.

Men i 400-tallet f. Kr. omfattede de Olympiske Lege så mange discipliner, at legene strakte sig over 5 dage, med fuldmånedagen som den midterste dag. På legenes første dag blev der ikke dystet. Atleterne blev mønstret og aflagde ed på, at de ville følge de olympiske regler og ikke snyde.

En usædvanlig konkurrence mellem herolder og trompeterer blev indført i $396 \mathrm{f}$. Kr. Dysten fandt sted ved indgangen til stadion med den såkaldte ekkohal som akustisk baggrund. Den herold, hvis stemme kunne høres videst omkring, vandt og fik den ære at åbne hver konkurrence med at udråbe atleternes navne, deres fædres navne samt navnet på deres hjemby. Efter kampen bekendtgjorde han med trompeteren sejrherrens navn.

Resten af dagen benyttede de tilrejsende til at orientere sig i helligdommen - træffe venner og bekendte - og ikke mindst til at diskutere praktiske og politiske spørgsmål. I det hele taget blev sådanne fælles græske begivenheder i det medieløse samfund brugt til gensidig information de mange bystater imellem. Politiske forhold, krige, handel og kultur blev diskuteret. Der foregik kunstnerisk optræden, nye billedværker og skulpturer blev præsenteret. På anden dagen begyndte legene for alvor.

Om formiddagen blev der afholdt konkurrencer med vognløb og hestevæddeløb på hippodromen. Hippodromen var en aflang bane med afrundet ende, delt på langs med to vendepunkter. På den ene kortside fandtes et specielt startsystem med båse, der åbnede sig efter tur, så alle deltagere var på linje ved væddeløbets begyndelse. En omgang var på ca. $1200 \mathrm{~m}$. Efter løbene var det som i dag vinderhestens ejer, som fik æren for sejren.

Efter væddeløbene blev der afholdt atletikkonkurrencer specielt for drenge (12-18 år).

Samme dags eftermiddag afholdtes mændenes femkamp (pentathlon), som indeholder helt andre discipliner end vore dages femkamp. De deltagende dystede i $400 \mathrm{~m}$ løb, diskoskast, spydkast, længdespring og brydning.

Under 400-meterløbet, der var et sprintløb, $1 \varnothing b$ deltagerne een gang frem og tilbage på stadion. Stadion var oprindelig en måleenhed på ca. $200 \mathrm{~m}$, som derefter blev betegnelsen for anlæg af denne længde. 

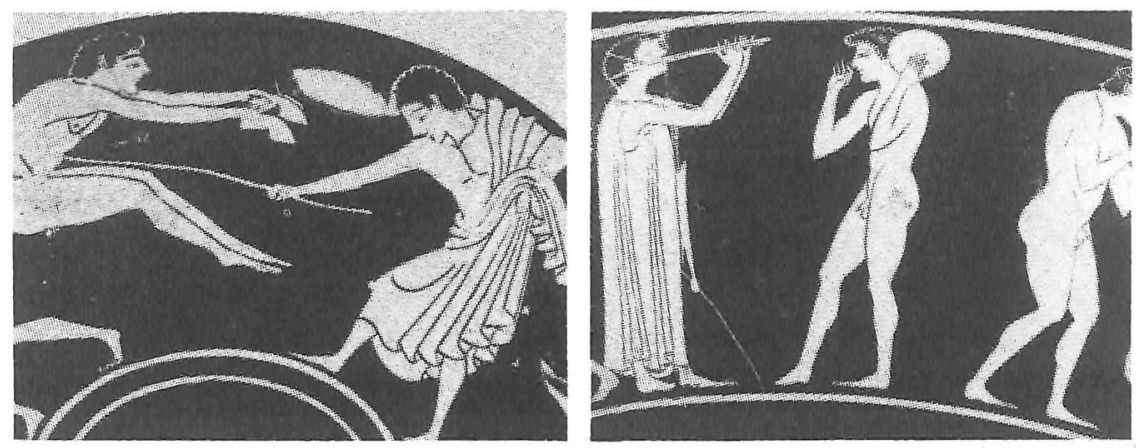

Groesk vasemaleri fra ca. $520 f$. Kr. malet af Euphiletos maleren. Sportsscener var yndede motiver $i$ groesk vasemaleri fra 500-tallet $f$. Kr. Her ses atleter fra pentathlon (femkamp), loengdespringer, spydkaster og diskoskaster.

Efter løb gik man over til diskoskast. På den berømte statue af billedhuggeren Myron ses diskoskasteren lige før kastet. Diskossen var oftest af bronze og vejede ca. $2,5 \mathrm{~kg}$, altså lidt tungere end vore dages diskos. I modsætning til den moderne diskoskaster drejede den antikke ikke rundt om sin egen akse under kastet, men tog afsæt alene ved hjælp af hoftens drejning.

Den næste disciplin i femkamp var spydkast - en sportsgren med militær oprindelse. Det foregik som i dag med till $\varnothing$ b, men omkring spydskaftet, der hvor man holdt fast, var snoet en lædersnor med løkke til pegefingeren. Lædersnoren fik spyddet til at rotere ved kastet.

Til længdespring, som var den næste disciplin, blev der benyttet håndvægte. Springet blev udført med tilløb og afsæt. Anvendelsen af håndvægtene forøgede ikke springlængden, men blev anset for at stabilisere springeren, så præstationen så harmonisk ud.

Femkamp afsluttedes med brydning. Der var tale om en voldelig kamp, hvor sejren først blev tilkendt, når modstanderen havde være i gulvet tre gange. Ligesom i de $\varnothing$ vrige discipliner kæmpede man nøgne. I brydning dog indsmurt i olie og sand, således at man bedre kunne få fat om hinanden. Efter kampen vaskede man sig ikke, men skrabede med en metalskraber olie, snavs og sand af sig.

Efter femkampens noget brutale afslutning, samledes alle om aftenen til en offerhandling ved Pelops grav.

På tredjedagen i det olympiske festprogram, blev der kun foretaget religiøse handlinger. Dagen indledtes med en festprocession, der udgik fra den administrative bygning, Prytaneion. Her tændtes fakler til den efterfølgende ofring ved Zeusalteret. Med faklerne i hænderne drog alle gennem helligdommen frem til det store Zeusalter, hvor et mægtigt dyreoffer blev foretaget. Om aftenen samledes deltagerne til en stor festmiddag, hvor det tiloversblevne offerk $\emptyset \mathrm{d}$ blev fortæret med masser af vin. 
På fjerdedagen var man igen klar til sportslegene. Om formiddagen blev der afholdt to former for løb, henholdsvis det korte sprintl $\varnothing \mathrm{b}$ på 400 meter og et langdistancel $\varnothing \mathrm{b}$ på flere 1000 meter. Langdistanceløbet blev afviklet ved, at deltagerne $1 \varnothing b$ stadion rundt fra 7 til 24 gange. Om eftermiddagen gik man over til de mere voldsomme discipliner: brydning, boksning og pankration (en kombination af brydning og nævekampe, hvor alle kneb gælder, undtagen bid og angreb mod øjnene). Til boksning blev der ikke anvendt boksehandsker, men istedet blev der viklet lange læderremme omkring knoerne for at beskytte dem mod slag. Først i romersk tid udviklede remmene sig til hele mordvåben, idet der under remmene blev lagt jernstykker.

Til slut afholdtes $l \varnothing b$ for hoplitter (fodsoldater). Deltagerne var ligesom de $\varnothing$ vrige atleter nøgne, bortset fra, at de bar hjelm og skjold. Denne afsluttende dyst synes i modstrid med våbenhvilen og forbudet mod at indføre våben $\mathrm{i}$ Elis under legene, men den skal vel ses som udtryk for den oprindelige sammenhæng mellem sport og militær.

På legenes femte dag blev sejrherrerne bekranset og gav de lovede ofre til guderne som tak for sejren. Om aftenen festedes atter, og de mest fornemme deltagere blev beværtet i prytaneion. Allerede næste dag drog tilskuere og atleter hjem til deres respektive byer, hvor nye festligheder ventede de sejrende.

\section{Sportslegene i historisk lys}

De Olympiske Lege er stærkt forankret i religion og mytologi; men så sandelig også i militære discipliner.

I Homers Iliade blev gravlegene for Patroklos beskrevet med afholdelse af blandt andet hestevæddel $\varnothing$ b. Homers digte er udtryk for en aristokratisk statsform, hvor den tidlige græske krigsførsel byggede på tunge og kostbare hestetrukne kampvogne.

I Olympia kunne principielt alle frie mandlige borgere deltage i de forskellige discipliner, uanset rigdom og stand, men i realiteten var formue en forudsætning, hvis man ville deltage i vognl $\varnothing \mathrm{b}$ og hestevæddel $\varnothing \mathrm{b}$.

I løbet af 600-tallet $\mathrm{f}$. Kr. blev antallet af sportsgrene udvidet til at omfatte flere voldsomme discipliner. En ændring, der igen kan ses i lyset af den historiske og militære udvikling. Sekshundrede tallets nye bystater havde krav om store hære med tungt bevæbnede hoplitter (fodfolk) bestående af alle byens frie borgere. Disse måtte have militær træning og her er sikkert en af de væsentligste årsager til, at atletikken kommer ind i græsk opdragelse.

Mange af de nyere sportsgrene var mere eller mindre militært begrundede, såsom spydkast, hoplitløb, brydning, boksning og pankration. Æren ved at sejre smittede af på sejrherrens by, jo flere sejrende atleter, desto stærkere hær. 
Dog allerede i 400-tallet f. Kr. - i de olympiske leges blomstringstid - sker der en vis professionalisering af sporten. Tendensen går mod sporten for dens egen skyld og for underholdningens skyld. Og der begynder at komme $\emptyset$ konomiske aspekter ind i billedet. Nok var det smukt og godt at vinde ære til sin bystat, men kransen, symbolet på sejr og ære, blev i hjembyen desuden honoreret med en form for statspension samt gratis bespisning på rådhuset. Selvom professionalisme i sig selv ikke blev betragtet som noget forkert, forekom der dog undertiden kritik af den overdrevne ære, som atleter var genstand for i deres hjembyer efter en sejr. Filosoffen Xenophanes skriver allerede omkring $520 \mathrm{f}$. Kr.:

"Men hvis en mand er sejrrig i løb eller pentathlon i Zeus' helligdom ved Pisas flod $i$ Olympia, er han aret i sine byfallers фjne med arespladser ved lege og fester og understøttelse på offentlig bekostning og en gave fra byens skatkam-

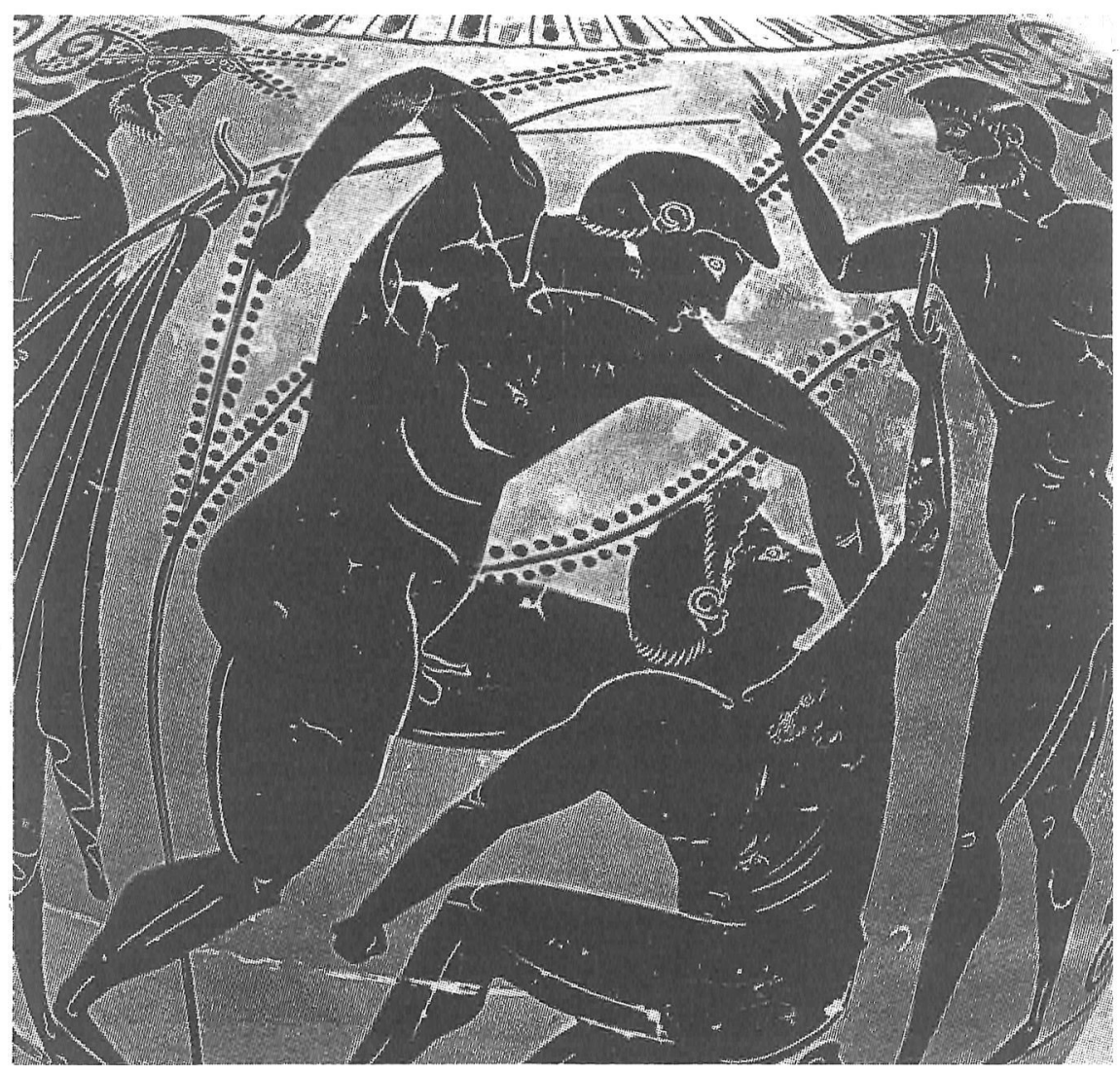

Graesk vasemaleri fra slutningen af 500-tallet $f$. Kr., malet af en maler fra Leagros gruppen. Der er tale om en scene fra pankration. Den besejrede atlet rakker fingeren op for at meddele dommeren, at han opgiver. 
mer ... Men han er ikke så fortjenstfuld som jeg, for vor visdom er bedre en mands og hestes styrke ... For skønt en by har en dygtig bokser ... vil den aldrig blive bedre ordnet .. eller dens kornkamre fyldt derved. «

Noget der for alvor satte skub i professionalismen og afmilitariseringen af græsk sport, var ændringen af statsstrukturen i 300-tallet f. Kr. (hellenistisk tid, efter Alexander den Stores død), hvor de små bystater underordnedes større statsdannelser. Bystaternes behov for egne soldater forsvandt hermed og atlettypen ændredes. Før i tiden havde atleterne været rekrutteret fra de frie borgers rækker - de som dannede bystaternes borgerhær. Atleterne betalte selv for træning og måtte være rimelig velstående for at kunne bruge tid og penge på at rejse til Olympia. Men efter 300-tallet bliver en karriere som professionel atlet en mulig levevej også for folk fra samfundets lavere sociale lag. Byerne underst $\varnothing t$ tter undertiden drenge og mænd med udprægede evner, så de kunne træne hyppigt.

Byerne afholdt undertiden også udgifter til træner og rejser. Denne finansieringsform medførte specialisering i enkelte sportsgrene - især blev boksning, brydning og pankration yndede discipliner.

Platon øjnede allerede i begyndelsen af 300-tallet $\mathrm{f}$. Kr. faren for, at professionalismen skulle have en skadelig virkning på ungdommen. Hans beskrivelse af en professionel atlet er ikke smigrende:

»Han er traeg af naturen, og den mindste forandring $i$ hans daglige rutine forårsager ham et alvorligt afbrck. "En anden kritisk røst var mere forarget over, at de lavere sociale lag fik chance for at deltage i de store lege: Den aristokratiske Alkibiades fra Athen nægtede således efter store sejre i Olympia i vognløb i $416 \mathrm{f}$. Kr. at deltage i legene mere, da han ikke brød sig om sine konkurrenters sociale baggrund.

Professionalismen medførte $\mathrm{i}$ hellenistisk og især i romersk tid en vis forgrovelse af sporten og tab af de oprindelige idealer. Dette kommer også til udtryk i øgede udsagn om korruption og snyderi i konkurrencerne. I det hele taget hører vi ikke meget til Olympia i romersk tid, selvom legene stadig blev afholdt hvert fjerde år. Vesterlændingene og især ikke romere interesserede sig ikke meget for sport; i hvert fald ikke for aktiv deltagelse. De foretrak rollen som tilskuere.

Det var en ny religion, der endelig satte stopper for de efterhånden hensygnende olympiske lege. Kristendommen så ikke mildt på disse fester, ikke så meget på grund af sporten selv, som på grund af dens nære forbindelse med hedensk religion. Sport og religion vedblev altid at være to sider af samme sag i Olympia. De kristne kejsere lukkede antagelig legene i 393 e. Kr., og snart efter gik helligdommen i forfald. Templerne blev ødelagt af de kristne og jordskælvene gjorde resten af arbejdet. Det antikke Grækenlands mest ærværdige helligdom blev glemt, og i århundreder blev stedet kun besøgt af får 
og hyrder, indtil den tyske arkæolog Ernst Curtius endelig for alvor i 1875 kunne begynde at afdække det Olympia, som i dag atter er blevet mødested for tusinder af turister fra alle egne af verden.

Nanna Westergård-Nielsen er klassisk arkæolog.

Aritklens illustrationer er taget fra:

Illustrierte Geschichte der Körperkultur Sportverlag Berlin, 1983. 